\title{
Hydrogen Peroxide Metabolism in Human Monocytes during Differentiation In Vitro
}

\author{
Akira Nakagawara, Carl F. Nathan, and Zanvil A. Cohn, Laboratory \\ of Cellular Physiology and Immunology, The Rockefeller University, New \\ York, 10021
}

A B S T RA C T The capacity of human blood monocytes to secrete hydrogen peroxide $\left(\mathrm{H}_{2} \mathrm{O}_{2}\right)$ and superoxide $\left(\mathrm{O}_{2}^{-}\right)$was measured as the cells differentiated during $4 \mathrm{wk}$ of culture. Morphologic transformation of monocytes into macrophages, epithelioid cells, and multinucleated giant cells accompanied a steady increase in the content of protein per cell, from $0.77 \mathrm{mg} /$ $10^{7}$ cells on days 0 to $11.77 \mathrm{mg} / 10^{7}$ cells on days 20 to 29. In contrast, secretion of $\mathrm{H}_{2} \mathrm{O}_{2}$ by adherent monocytes was $859 \pm 73 \mathrm{nmol} / 60 \mathrm{~min}$ per $\mathrm{mg}$ protein (mean \pm SEM, $n=18$ ) on day 0 , rose $40 \%$ on day 3 , and then fell rapidly, remaining below $6 \%$ of the initial values after day 10. The decline in capacity to secrete reactive oxygen intermediates was observed whether $\mathrm{H}_{2} \mathrm{O}_{2}$ or $\mathrm{O}_{2}^{-}$were measured, whether the cells were challenged with phorbol myristate acetate or with opsonized zymosan, and whether the results were expressed per milligram cell protein or per cell.

Superoxide dismutase activity tripled in adherent monocytes from day 0 to day 3 , and thereafter remained elevated through at least day 16 . In contrast, the activity of myeloperoxidase declined rapidly, catalase and glutathione peroxidase declined more gradually, and glutathione reductase and glutathione remained constant throughout the period of observation. Thus, the decline in capacity to secrete $\mathrm{H}_{2} \mathrm{O}_{2}$ could not be attributed to increases in cellular levels of these antioxidants.

On the first day of culture, $\mathrm{H}_{2} \mathrm{O}_{2}$ release was enhanced up to fourfold by inclusion of sodium azide or potassium cyanide in the assay medium. This enhancement appeared to be due to inhibition of monocyte

\footnotetext{
A preliminary report of this study was presented at the Annual Meeting of the American Society for Clinical Investigation, 27 April 1981, San Francisco, Calif., and published in abstract form. (Clin. Res. 29: 533A).

Dr. Nathan is a scholar of the Leukemia Society of America and a research career awardee of the Irma T. Hirschl Trust. Reprint requests should be addressed to Dr. Nathan, The Rockefeller University. Dr. Nakagawara's present address is Department of Pediatric Surgery, Kyushu University School of Medicine, Fukuoka 812, Japan.
}

myeloperoxidase, rather than catalase. This conclusion was based on the kinetics and dose-response relationships for the effects of azide and cyanide on $\mathrm{H}_{2} \mathrm{O}_{2}$ release and on the activities of catalase and myeloperoxidase.

Thus, the differentiation of human monocytes into macrophages in vitro is accompanied by an apparent reduction in the capacity to produce $\mathrm{H}_{2} \mathrm{O}_{2}$ and $\mathrm{O}_{2}^{-}$. In this regard, the human monocyte-derived macrophage comes to resemble the resting tissue macrophage previously characterized in the mouse peritoneal cavity.

\section{INTRODUCTION}

More than $\mathbf{5 0}$ years ago, investigators observed blood monocytes differentiate into macrophages, epithelioid cells, and giant cells over days or weeks in vitro (1-3). Such observations have been confirmed repeatedly $(4$, 5 ) and extended to document increases in cell size, protein content, lysosomal and ectoenzyme activity, surface receptor expression, and phagocytic capacity $(4,6-12)$. This differentiation sequence in vitro closely parallels that observed when monocytes emigrate from the vasculature into the tissues (13-15).

The freshly isolated human blood monocyte responds to soluble and particulate surface-active stimuli by the secretion of superoxide anion (16-20) and hydrogen peroxide (17) in amounts similar to those released by granulocytes $(17,18)$. The production of these reactive oxygen intermediates is of considerable interest, in view of mounting evidence for their involvement in some of the antimicrobial (21-24) and antitumor (25-27) activities of mononuclear phagocytes, together with the recent finding that monocyte superoxide release is suppressed in some patients with cancer and elevated during certain infections. ${ }^{1}$

In the mouse, macrophages from uninflamed tissues secrete little $\mathrm{O}_{2}^{-}$and $\mathrm{H}_{2} \mathrm{O}_{2}(28-30)$. When they have

\footnotetext{
${ }^{1}$ Nakagawara, A. Submitted for publication.
} 
been activated by exposure to inflammatory agents or lymphocyte mediators, their capacity to secrete these substances increases toward the high levels observed with human blood monocytes $(23,29-31)$. We hypothesized, therefore, that the ability of the blood monocyte to secrete large amounts of $\mathrm{O}_{2}^{-}$and $\mathrm{H}_{2} \mathrm{O}_{2}$ might $(a)$ normally involute during its maturation into a macrophage; and $(b)$ that this capacity might be retained or regained in the presence of lymphocyte mediators. The present study tests the first part of this proposed sequence of differentiation.

\section{METHODS}

Preparation of mononuclear leukocytes $(M N L){ }^{2}$ Healthy adult volunteers of both sexes were phlebotomized at the Greater New York Blood Center. $450 \mathrm{ml}$ blood was collected into $63 \mathrm{ml}$ of anticoagulant CDPA-1 (hydrous dextrose, $1.61 \mathrm{~g}$; sodium citrate dihydrate, $1.66 \mathrm{~g}$; anhydrous citric acid, $0.19 \mathrm{~g}$; sodium biphosphate, $0.14 \mathrm{~g}$; adenine, $0.017 \mathrm{~g}$ ). We obtained the buffy coat $2-3 \mathrm{~h}$ after venipuncture, and separated MNL by a modification of the method of Böyum (32). Buffy coat was diluted with an equal volume of $0.9 \% \mathrm{NaCl}$, and $30 \mathrm{ml}$ of the cell suspension was layered on $15 \mathrm{ml}$ of FicollHypaque ( $d=1.077$, Pharmacia Fine Chemicals, Piscataway, N. J.) in 50-ml polypropylene conical tubes (No. 2533, Corning Glass Works, Corning, N. Y.). After centrifugation at $700 \mathrm{~g}$ for $20 \mathrm{~min}$ at $25^{\circ} \mathrm{C}$, the upper cell layer was collected and centrifuged at $400 \mathrm{~g}$ for $10 \mathrm{~min}$ at $4^{\circ} \mathrm{C}$. The sedimented cells were suspended in $20 \mathrm{ml}$ of RPMI 1640 (Flow Laboratories, Rockville, Md.) and centrifuged at $100 \mathrm{~g}$ for $10 \mathrm{~min}$ at $4^{\circ} \mathrm{C}$. The final pellet was resuspended in RPMI 1640 containing $25 \%$ human serum (see below), $100 \mu \mathrm{g} / \mathrm{ml}$ streptomycin and $100 \mathrm{U} / \mathrm{ml}$ penicillin ("medium") to give $1 \times 10^{7}$ $\mathrm{MNL} / \mathrm{ml}$. The average yield of MNL at this stage was 3.5 $\times 10^{8}$ cells (mean of 13 experiments), with a differential count of $32 \%$ monocytes, $67 \%$ lymphocytes, and $1 \%$ granulocytes after staining with Diff-Quik (Harleco, American Hospital Supply Corp., Philadelphia, Pa.). Of the mononuclear cells, $\sim 27 \%$ (mean of nine experiments) were peroxidase positive by the method of Kaplow (33).

Preparation of serum. $450 \mathrm{ml}$ of human blood of any blood type was obtained from the Greater New York Blood Center immediately after collection without anticoagulant. The blood was held at room temperature for $60 \mathrm{~min}$, and then at $4^{\circ} \mathrm{C}$ for 75 min, before centrifugation at $140 \mathrm{~g}$ for $10 \mathrm{~min}$ at $4^{\circ} \mathrm{C}$. The supernate was centrifuged again at $1,500 \mathrm{~g}$ for $15 \mathrm{~min}$ at $4^{\circ} \mathrm{C}$, filtered ( $0.45 \mu \mathrm{m}$, Nalge Co., Rochester, N. Y.), aliquotted, and stored at $-80^{\circ} \mathrm{C}$ until use.

Culture of monocytes. 13-mm Diam glass coverslips (Clay-Adams, New York) were soaked in $70 \%$ ethanol for at least $5 \mathrm{~d}$, then dipped in $95 \%$ ethanol, flamed, and placed in 100 -mm plastic petri dishes. $1 \times 10^{6} \mathrm{MNL}$ in $0.1 \mathrm{ml}$ medium were layered carefully over each coverslip. After incubation for $2 \mathrm{~h}$ at $37^{\circ} \mathrm{C}$ in $5 \% \mathrm{CO}_{2} / 95 \%$ humidified air, the petri dish was filled with Hanks' balanced salt solution (HBSS, Flow Laboratories, McLean, Va.) at $37^{\circ} \mathrm{C}$ and gently agitated. The HBSS was removed, and the rinsing process repeated twice

\footnotetext{
${ }^{2}$ Abbreviations used in this paper: GPO, glutathione peroxidase; GR, glutathione reductase; MNL, mononuclear leukocytes; HPO, horseradish peroxidase; KRPG, KrebsRinger phosphate buffer with glucose; MPO, myeloperoxidase; PMA, phorbol myristate acetate; SOD, superoxide dismutase.
}

more. Individual coverslips were then transferred to $16-\mathrm{mm}$ Diam plastic wells in 24-well trays (Costar Data Packaging, Cambridge, Mass.) in $0.3 \mathrm{ml}$ of medium. The medium was replaced on days $1,3,5$, and 7 , and thereafter every $4 \mathrm{~d}$. For enzyme and glutathione assays, $4 \times 10^{7} \mathrm{MNL}$ were plated in 2 $\mathrm{ml}$ medium in 35-mm Diam Pyrex glass petri dishes, or $1 \times 10^{8}$ MNL in $6 \mathrm{ml}$ medium were plated in 85-mm Diam Pyrex dishes, and otherwise processed as for coverslips.

Cell counts and protein measurements. Coverslips were washed four times in $0.9 \% \mathrm{NaCl}$, drained briefly on absorbent paper, and transferred to a dry Costar well. $0.05-0.20 \mathrm{ml}$ of nuclear staining solution was layered over each coverslip, consisting of $0.1 \mathrm{M}$ citric acid, $0.05 \%$ naphthol blue black (Allied Chemical Corp., New York), and 1.0\% Triton X-100. After $30 \mathrm{~min}$ at room temperature, the suspension of nuclei was mixed in a pipette tip, transferred to a hemocytometer, and counted. Separate coverslips stained with Diff-Quik were used to determine the average number of nuclei per cell after counting 400 cells. The number of nuclei per coverslip was divided by the average number of nuclei per cell to give the number of cells per coverslip. Matched coverslips were rinsed in $0.9 \% \mathrm{NaCl}$ as above, dried, dissolved in $0.3 \mathrm{ml}$ of $0.5 \mathrm{~N} \mathrm{NaOH}$, and assayed for protein by the method of Lowry et al. (34) with bovine serum albumin as a standard. Determinations of cell number and of adherent cell protein were performed in triplicate at each time point.

Measurement of $\mathrm{H}_{2} \mathrm{O}_{2}$ release. In preliminary experiments, $\mathrm{H}_{2} \mathrm{O}_{2}$ release from monocytes adherent to $13 \times 27-\mathrm{mm}$ glass coverslips was observed continuously by measuring the oxidation of scopoletin (Sigma Chemical Co., St. Louis, Mo.) in the presence of 1 purpurogallin unit (PU) of horseradish peroxidase (HPO), Type II (Sigma) in $3.0 \mathrm{ml}$ of modified Krebs-Ringer phosphate buffer with glucose (KRPG) (137 mM $\mathrm{NaCl}, 4.9 \mathrm{mM} \mathrm{KCl}, 0.5 \mathrm{mM} \mathrm{CaCl}_{2}, 1.2 \mathrm{mM} \mathrm{MgSO}_{4}, 5.5 \mathrm{mM}$ glucose, $5.7 \mathrm{mM}$ sodium phosphate, $\mathrm{pH} 7.35$ ) in the presence of $1 \mathrm{mM} \mathrm{NaN}_{3}$ (Fisher Scientific Co., Fair Lawn, N. J.) in a $37^{\circ} \mathrm{C}$ thermostated Perkin-Elmer-Hitachi MPF-44A fluorometer, as described (28). After stimulation with phorbol myristate acetate (PMA) (Consolidated Midlands, Brewster, N. Y.). or opsonized zymosan (see below), $\mathrm{H}_{2} \mathrm{O}_{2}$ release commenced within $3 \mathrm{~min}$, continued at a nearly constant rate for $\sim 40 \mathrm{~min}$, and ceased at $\sim 70-90 \mathrm{~min}$. Therefore, standard assays were performed as follows. Adherent monocytes on 13-mm Diam coverslips were washed thoroughly by swirling the coverslip in four successive beakers of $0.9 \% \mathrm{NaCl}$ at room temperature, drained on absorbent paper, and placed in 16-mm Costar wells containing $1.5 \mathrm{ml} \mathrm{KRPG}$, from 2 to $35 \mathrm{nmol}$ scopoletin, 0.5 PU HPO, and $150 \mathrm{ng}$ PMA (dissolved in dimethylsulfoxide [DMSO], with final DMSO concentration of $0.033 \%$ ). As controls, cell-free coverslips were rinsed in the same manner and carried through the assay. The Costar trays were placed in a $37^{\circ} \mathrm{C}$ water bath for $60 \mathrm{~min}$, the supernatant fluid removed, and its fluorescence determined at room temperature as described (28). To use opsonized zymosan as a stimulus, $40 \mathrm{mg}$ zymosan (Sigma) was suspended in $5 \mathrm{ml} 0.9 \% \mathrm{NaCl}$ with $10 \%$ human serum prepared as described above. After 30 min at $37^{\circ} \mathrm{C}$, the particles were washed twice by centrifugation in $0.9 \% \mathrm{NaCl}$ and stored at $-80^{\circ} \mathrm{C}$ until use. $2.0 \times 10^{7}$ zymosan particles were added to the $\mathrm{H}_{2} \mathrm{O}_{2}$ reaction mixture instead of PMA. The Costar plate was centrifuged at $340 \mathrm{~g}$ for $2 \mathrm{~min}$ at $25^{\circ} \mathrm{C}$ to initiate contact of the particles with the monocytes. All $\mathrm{H}_{2} \mathrm{O}_{2}$ release assays were performed with triplicate coverslips. In preliminary experiments, no $\mathrm{H}_{2} \mathrm{O}_{2}$ release was detected in the absence of PMA or zymosan. These controls were omitted from subsequent experiments.

Measurement of $\mathrm{O}_{2}^{-}$release. 13-mm Diam coverslips containing adherent monocytes were rinsed as for the $\mathrm{H}_{2} \mathrm{O}_{2}$ assay and transferred to Costar wells containing $0.75 \mathrm{ml}$ 
KRPG with $100 \mu \mathrm{M}$ ferricytochrome $c$ (Sigma) with or without $40 \mu$ g superoxide dismutase (SOD) (Sigma). After $10 \mathrm{~min}$ at $37^{\circ} \mathrm{C}$, PMA (75 $\left.\mathrm{ng}\right)$ or opsonized zymosan $\left(2.0 \times 10^{7}\right)$ were added. The particles were sedimented by centrifugation at $340 \mathrm{~g}$ for $2 \mathrm{~min}$ at $25^{\circ} \mathrm{C}$. After $60 \mathrm{~min}$ at $37^{\circ} \mathrm{C}$, the trays were cooled to $4^{\circ} \mathrm{C}$ and the zymosan removed from the medium by centrifugation at $400 \mathrm{~g}$ for $5 \mathrm{~min}$. Superoxide release was determined from the optical density at $550 \mathrm{~nm}$ of samples without $S O D$, minus the $\mathrm{OD}_{550}$ of matched samples containing SOD, using a molar extinction coefficient of $21.0 \times 10^{3}$ $\mathrm{cm}^{-1}$. All samples were assayed in triplicate.

Myeloperoxidase. The $0.05 \%$ Triton X-100 lysate of rinsed, adherent monocytes was assayed for peroxidatic activity using $o$-dianisidine (Sigma) as substrate by the method of Steinman and Cohn (35). Triton did not interfere with the assay.

Catalase. The $1.0 \%$ Triton X-100 lysate was centrifuged at $4^{\circ} \mathrm{C}$ for $15 \mathrm{~min}$ in an Eppendorf microfuge (Brinkmann Instruments, Westbury, N. Y.). The supernate was assayed for catalase by the method of Baudhuin et al. (36). Triton did not interfere with the assay. In addition, the generation of oxygen from exogenous $\mathrm{H}_{2} \mathrm{O}_{2}$ in the presence of cell lysate was measured polarographically with a Clark type oxygen electrode (Yellow Springs Instrument Co., Yellow Springs, Ohio) by the method of Roos et al. (37).

Glutathione peroxidase (GPO) and glutathione reductase (GR). The supernatant of $0.2 \%$ Triton X-100 lysates was assayed for GPO by the method of Paglia and Valentine (38) and for GR by the method of Roos et al. (39).

Superoxide dismutase. The supernate of the $0.2 \%$ Triton $\mathrm{X}-100$ lysate was assayed according to McCord and Fridovich (40) using sufficient lysate to obtain $50 \%$ inhibition of the rate of reduction of cytochrome $c$, which was defined as $1 \mathrm{U}$ of SOD under the stated conditions (40). Under these conditions, there appeared to be no significant contribution by cytochrome oxidase or cytochrome peroxidase, because the observed activity was unaffected by $20 \mu \mathrm{M} \mathrm{KCN} \mathrm{(41).}$

Glutathione. The $0.05 \%$ Triton X-100 lysate was deproteinated with $2.5 \%$ sulfosalicylic acid, and the supernate analyzed by the method of Tietze (42). Values are reported as nanomoles of the tripeptide (reduced plus oxidized) per milligram cell protein.

Statistics. Data shown from individual experiments are the means of triplicate samples except as noted in the figure legend. Results of pooled experiments are given as means \pm SEM where each datum is the mean of triplicates. In Fig. 5 , results were shown as means \pm SD. Significance was determined by Student's $t$ test.

\section{RESULTS}

Differentiation of monocytes into macrophages in vitro. Our culture conditions supported the longterm survival and maturation of monocytes into macrophages, epithelioid cells, and giant cells, as assessed by morphology and measurement of protein content per coverslip and per cell. As shown in Fig. 1, the adherent protein content per coverslip was nearly constant for the first $3 \mathrm{~d}$ of culture, then declined to $\sim 40 \%$ by day 7 . The nonadherent cells collected during the 1st wk were $60 \%$ viable by trypan blue exclusion. Their ability to release $\mathrm{H}_{2} \mathrm{O}_{2}$ is discussed below. After day 7 , the adherent protein content per coverslip increased steadily, coincident with the appearance of binucleate cells (from days 5-6) and of giant cells with 3-16 nuclei (from day 7). Giant cell formation was observed in the

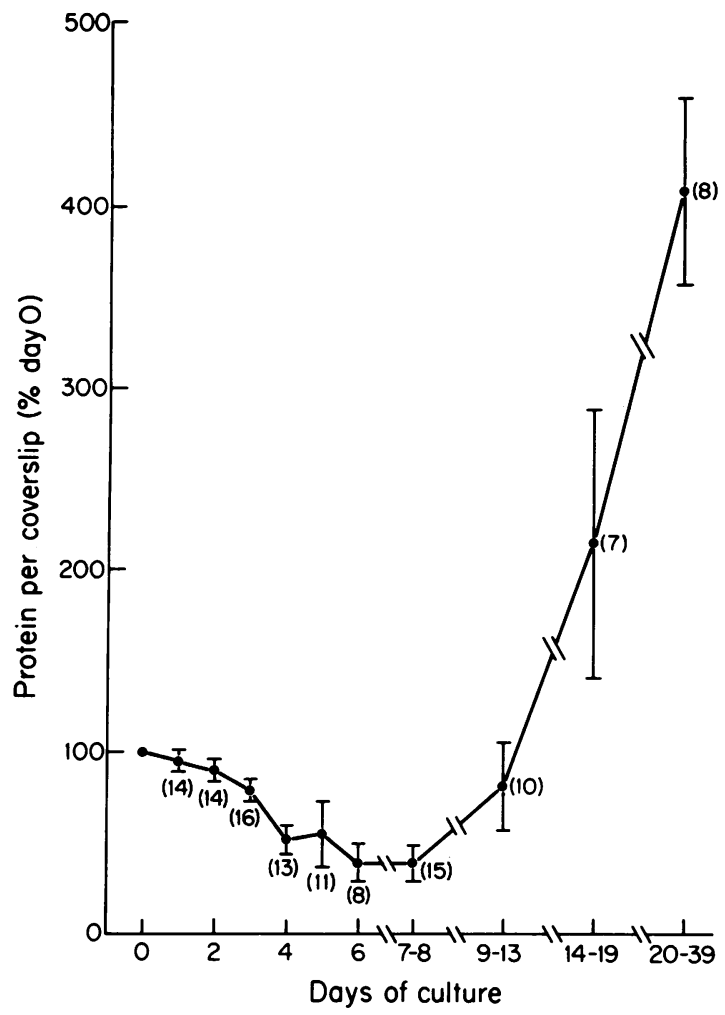

Figure 1 Change in adherent cell protein per coverslip during culture of human monocytes. The day 0 value was $18.2 \pm 1.1 \mu \mathrm{g} /$ coverslip (mean $\pm \mathrm{SEM}, n=17$ ). Values are expressed as means \pm SEM for the number of experiments shown in parentheses. Each experiment had triplicate coverslips.

cultures from $\sim 60 \%$ of donors; in these samples, giant cells comprised from 2 to $80 \%$ of the cells after the 2 nd wk. The protein content per adherent cell increased from $0.77 \pm 0.05 \mathrm{mg} / 10^{7}$ cells $(n=7)$ on day 0 to values that were approximately twice as great on day 4 , three times as great on day 7 , and 15 times as great on days 20-29 (Fig. 2).

$\mathrm{H}_{2} \mathrm{O}_{2}$ release from adherent monocytes: assay conditions. In matched coverslips, values for $\mathrm{H}_{2} \mathrm{O}_{2}$ release exceeded those for $\mathrm{O}_{2}^{-}$release (Table $\mathrm{I}$, line 1). With complete recovery of both substances, the expected ratio would be the reverse, namely $2: 1:: \mathrm{O}_{2}^{-}: \mathrm{H}_{2} \mathrm{O}_{2}$ (41). Therefore, we devoted most experiments to measurements of $\mathrm{H}_{2} \mathrm{O}_{2}$ release, which apparently provided a better estimate of the cells' capacity to reduce molecular $\mathrm{O}_{2}$. In preliminary experiments, concentrations of PMA over the range 0.01 to $1,000 \mathrm{ng} / \mathrm{ml}$ and of opsonized zymosan over the range 10 to 150 particles per cell, were tested. Half-maximal stimulation by PMA required $2.5 \mathrm{ng} / \mathrm{ml}$; maximal stimulation was seen with $10 \mathrm{ng} / \mathrm{ml}(16.7 \mathrm{nM})$. Maximal stimulation by opsonized zymosan followed the addition of 40 particles/cell. Under these conditions, $>95 \%$ of the cells ingested zymosan particles, whether tested on day 0 


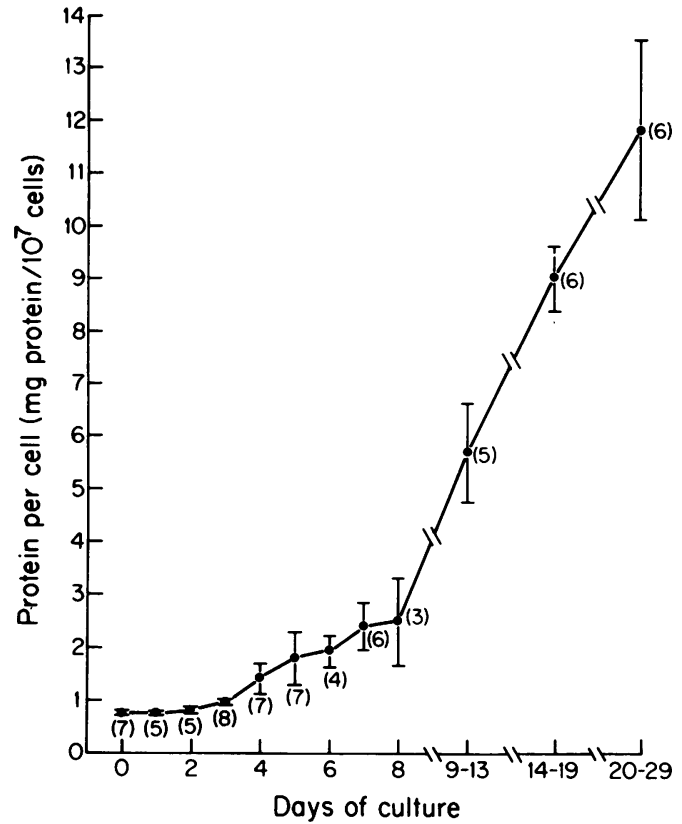

FIGURE 2 Change in protein per cell during maturation of human monocytes in vitro. Cell number per coverslip was determined as in Methods. Values given are means \pm SEM for the number of experiments shown in parentheses (each in triplicate).

or on day 14 of culture. The dependence of $\mathrm{H}_{2} \mathrm{O}_{2}$ release upon $\mathrm{pH}$ of the assay buffer was studied on day 0 , day 1 , and day 5 , and gave similar profiles at each time (Fig. 3), with optimal values between $\mathrm{pH} 7.2$ and 8.2. The abrupt decrease in $\mathrm{H}_{2} \mathrm{O}_{2}$ release at acid $\mathrm{pH}$ was not due to the inhibition of HPO by azide at low $\mathrm{pH}$, because authentic $\mathrm{H}_{2} \mathrm{O}_{2}$ oxidized the same amount of scopoletin in the range from $\mathrm{pH} 5.3$ to $\mathrm{pH}$ 8.0. Cell density has been reported to affect $\mathrm{O}_{2}^{-}$release from mouse macrophages (29). Therefore, we compared $\mathrm{H}_{2} \mathrm{O}_{2}$ release from adherent monocytes as a function of the number of cells per coverslip. As shown in Fig. 4,

TABLE I

Comparison of Superoxide and Hydrogen Peroxide Release from Monocytes Induced by PMA or Opsonized Zymosan at Different Times in Culture

\begin{tabular}{|c|c|c|c|c|}
\hline \multirow{2}{*}{$\begin{array}{l}\text { Days of } \\
\text { culture }\end{array}$} & \multicolumn{2}{|c|}{ PMA* } & \multicolumn{2}{|c|}{ Opsonized zymosan } \\
\hline & $\mathrm{O}_{2}^{-}$ & $\mathrm{H}_{2} \mathrm{O}_{2}$ & $\mathrm{O}_{\mathbf{2}}^{-}$ & $\mathrm{H}_{2} \mathrm{O}_{2}$ \\
\hline & \multicolumn{4}{|c|}{ nmol $/ 60 \mathrm{~min} / \mathrm{mg}$ protein } \\
\hline $\mathbf{0}$ & $344 \pm 36$ & $877 \pm 32$ & $199 \pm 17$ & $612 \pm 33$ \\
\hline 3 & $195 \pm 48$ & $1,001 \pm 121$ & $143 \pm 31$ & $364 \pm 87$ \\
\hline 14 & $4 \pm 2$ & $20 \pm 10$ & $0 \pm 0$ & $31 \pm 6$ \\
\hline
\end{tabular}

* $100 \mathrm{ng} / \mathrm{ml}$.

\$ 100 particles added per cell.

$\$$ Mean \pm SEM for triplicates.

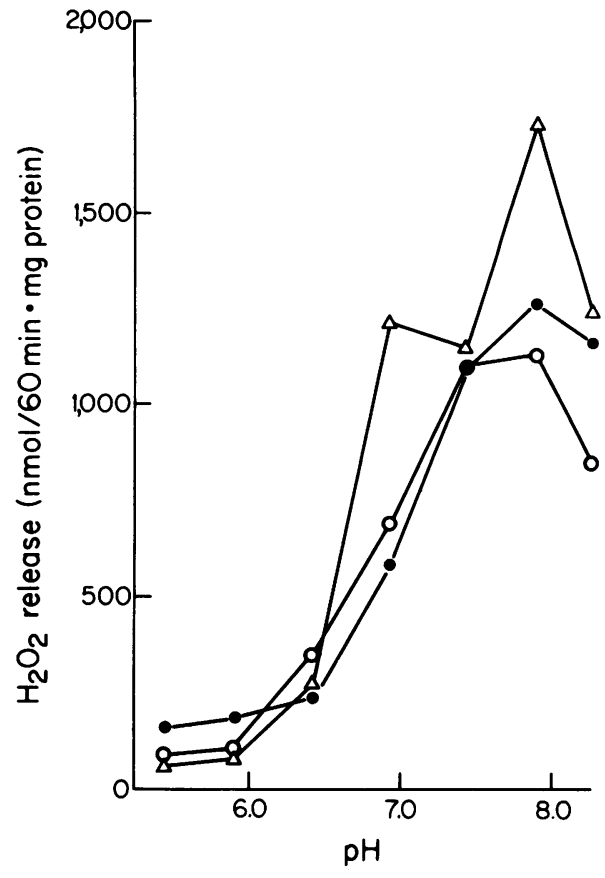

Figure 3 Effect of $\mathrm{pH}$ on $\mathrm{H}_{2} \mathrm{O}_{2}$ release by monocytes or monocyte-derived macrophages. The $\mathrm{pH}$ of phosphate buffer in KRPG was adjusted to the indicated values while holding phosphate concentration constant. The reaction was triggered by $100 \mathrm{ng} / \mathrm{ml}$ PMA. 9 , day 0 ; $\bigcirc$, day $1 ; \Delta$, day 5.
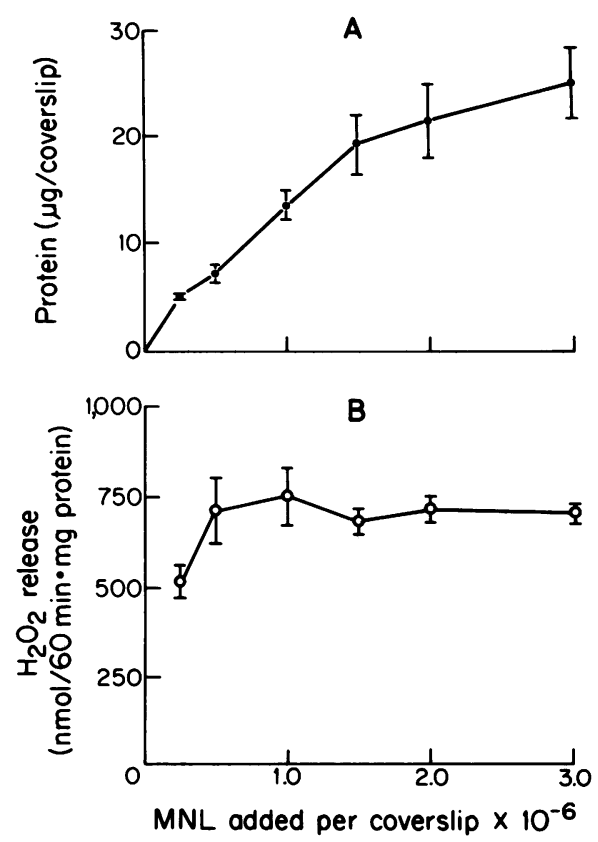

Figure 4 Effect of cell density on $\mathrm{H}_{2} \mathrm{O}_{2}$ release by day 0 monocytes. The various concentrations of mononuclear leukocytes suspended in culture medium were mounted on coverslips, and incubated for $2 \mathrm{~h}$ at $37^{\circ} \mathrm{C}$ in $5 \% \mathrm{CO}_{2}$-air. After vigorous washing, (A) the protein content and (B) PMAinduced $\mathrm{H}_{2} \mathrm{O}_{2}$ releasing activity were measured. Values are expressed as means \pm SD from four experiments. 
$\mathrm{H}_{2} \mathrm{O}_{2}$ release per milligram protein was independent of the number of monocytes adhering.

Changes in $\mathrm{H}_{2} \mathrm{O}_{2}$ release with time in culture. On day 0 , adherent monocytes from 18 donors released an average of $859 \pm 73 \mathrm{nmol} \mathrm{H}_{2} \mathrm{O}_{2} / 60 \mathrm{~min}$ per $\mathrm{mg}$ protein after stimulation by PMA. As shown in Fig. 5, there was a statistically significant decline to $73 \%$ of the initial value on day 1 , followed by a statistically significant increase to $140 \%$ of the initial value on day 3 . Thereafter, $\mathrm{H}_{2} \mathrm{O}_{2}$ release decreased rapidly. After day 10 , values were below $6 \%$ of the day 0 value. The foregoing values were expressed per milligram cell protein. However, overall results were similar if the values were expressed per cell, even though the cells increased progressively in size during the same period (Fig. 6). The decline in $\mathrm{H}_{2} \mathrm{O}_{2}$-releasing capacity of adherent cells was not due to a selective detachment of more active cells. When the cells detaching from day 0 to day 5 were collected and assayed in suspension, they released $6.9 \mathrm{nmol} \mathrm{H}_{2} \mathrm{O}_{2} / 60$ min per $10^{5}$ cells, a value almost the same as that of the adherent cells tested on day 5 .

Using opsonized zymosan as a stimulus instead of PMA, $\mathrm{H}_{2} \mathrm{O}_{2}$ release also declined markedly from day 0 to day 14 (Table I). However, values on day 3 were lower than on day 0 , rather than being somewhat elevated, as seen with PMA (Table I). The timedependent decline in $\mathrm{H}_{2} \mathrm{O}_{2}$ release in response to opsonized zymosan could not be attributed to differences in phagocytosis of the particles. The percentage of phagocytic cells remained constant $(\sim 95 \%)$, and the mean number of particles per cell actually increased from day 0 (5) to day 14 (35) (means of two experiments).

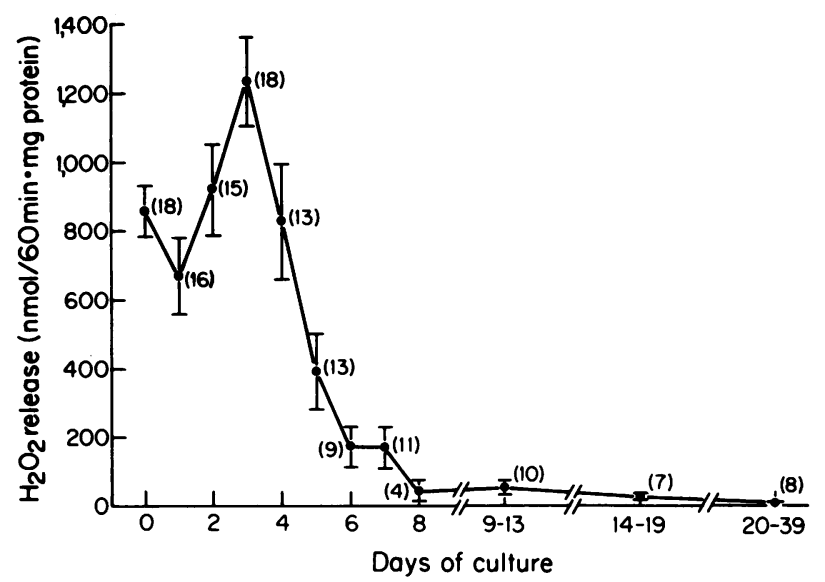

Figure 5 Change in $\mathrm{H}_{2} \mathrm{O}_{2}$ release based on $\mathrm{mg}$ cell protein during culture of human monocytes in vitro. Values are expressed as means \pm SEM for the number of experiments shown in parentheses, each done in triplicate. The reaction was triggered by $100 \mathrm{ng} / \mathrm{ml}$ PMA. Except for days 2 and 4, each point is significantly different from the day 0 point. The $P$ values are: $<0.1$ (day 1 ), $<0.01$ (days 3 and 5), and $<0.001$ (all other points).

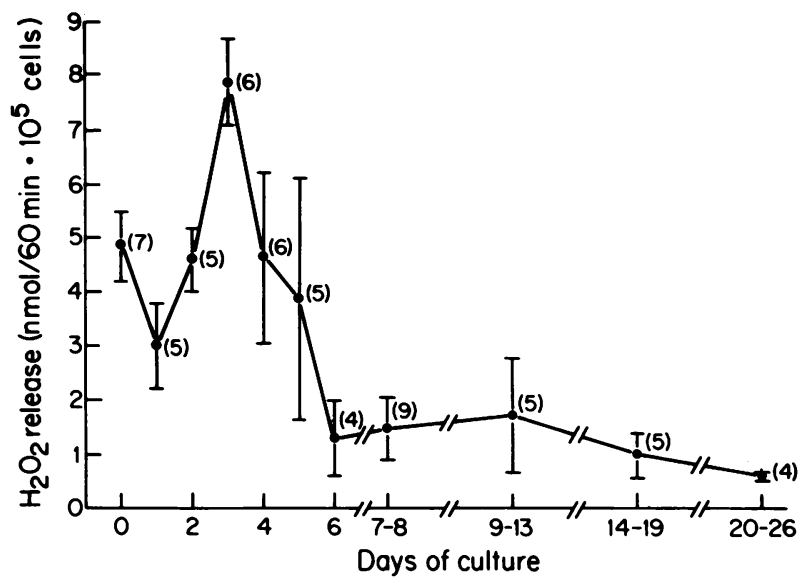

Figure 6 Change in $\mathrm{H}_{2} \mathrm{O}_{2}$ release based on cell number during culture of monocytes. PMA $(100 \mathrm{ng} / \mathrm{ml})$ was used as the triggering agent. Means $\pm S E M$ (number of experiments).

Changes in $\mathrm{O}_{2}^{-}$release with time in culture. With either PMA or opsonized zymosan as a stimulus, $\mathrm{O}_{2}^{-}$release was about one-third as great as $\mathrm{H}_{2} \mathrm{O}_{2}$ release on day 0 , and declined progressively to barely detectable levels by day 14 (Table I).

Changes in scavengers of $\mathrm{O}_{2}^{-}$and $\mathrm{H}_{2} \mathrm{O}_{2}$ during differentiation. As shown in Table II, the specific cellular activity of SOD increased an average of threefold on day 3 compared with day 0 . This was of considerable interest, in view of the increased release of $\mathrm{H}_{2} \mathrm{O}_{2}$ and the decreased release of $\mathrm{O}_{2}^{-}$observed on day 3 . Thereafter, SOD levels remained nearly constant through day 16. In contrast, catalase levels declined after day 3 , reaching $<10 \%$ of initial values by the 3 rd wk of culture. GPO decreased less markedly, reaching about one-third of the initial value by day 22 . GR and glutathione levels were nearly constant throughout the same period. Finally, myeloperoxidase (MPO) activity decreased rapidly after day 0 (Table III). Thus, there was no evidence that an increase in peroxidecatabolizing pathways could account for the decreased release of $\mathrm{H}_{2} \mathrm{O}_{2}$ observed during differentiation of monocytes in culture.

Importance of inhibition of myeloperoxidase for measurement of $\mathrm{H}_{2} \mathrm{O}_{2}$ release. As noted, changes in the activities of $\mathrm{H}_{2} \mathrm{O}_{2}$-catabolizing substances with time in culture did not appear to account for decreases in $\mathrm{H}_{2} \mathrm{O}_{2}$ release after day 4. However, intracellular $\mathrm{H}_{2} \mathrm{O}_{2}$-scavengers did exert a profound effect on observed levels of $\mathrm{H}_{2} \mathrm{O}_{2}$ release during the first $3 \mathrm{~d}$ of culture. This was reflected by the fact that $\mathrm{H}_{2} \mathrm{O}_{2}$ release was 4.3-fold greater on day 0 in the presence of $1 \mathrm{mM}$ $\mathrm{NaN}_{3}$ than in its absence. The $\mathrm{H}_{2} \mathrm{O}_{2}$ release-enhancing effect of azide decreased with time in culture in parallel with the decrease in specific activity of myeloperoxidase (Table III), but without relation to levels of 
TABLE II

Changes in $\mathrm{O}_{2}^{-}$and $\mathrm{H}_{2} \mathrm{O}_{2}$ Scavengers during Differentiation of Human Monocytes In Vitro*

\begin{tabular}{ccccccc}
\hline $\begin{array}{c}\text { Days of } \\
\text { culture }\end{array}$ & $\begin{array}{c}\mathrm{H}_{2} \mathrm{O}_{2} \\
\text { release }\end{array}$ & SOD & Catalase & GPO & GR & GSH + GSSG \\
\hline $\begin{array}{c}\text { nmol/60 min/ } \\
\text { mg protein }\end{array}$ & U/mg protein & $\begin{array}{c}\times 10^{-1} \text { BUI } \\
\text { mg protein } \$\end{array}$ & $\begin{array}{c}\text { nmol/min/mg } \\
\text { protein }\end{array}$ & $\begin{array}{c}\text { nmol/min/mg } \\
\text { protein }\end{array}$ & nmol/mg protein \\
0 & $750 \pm 16$ & $13 \pm 3$ & $25.1 \pm 0.4$ & $264 \pm 8$ & $71 \pm 2$ & $41.3 \pm 0.4$ \\
3 & $1339 \pm 81$ & $41 \pm 10$ & $28.7 \pm 1.2$ & $243 \pm 6$ & $66 \pm 2$ & $37.4 \pm 1.0$ \\
10 & $194 \pm 19$ & $36 \pm 12$ & $15.5 \pm 1.1$ & $160 \pm 10$ & $76 \pm 7$ & $45.6 \pm 1.2$ \\
22 & $\mathrm{ND}$ & $46 \pm 23^{* *}$ & $2.2 \pm 0.1$ & $80 \pm 7$ & $77 \pm 2$ & $32.9 \pm 0.5$ \\
\hline
\end{tabular}

* Mean \pm SD for triplicates from a single donor, except three separate experiments for SOD on day 0 and two experiments for SOD on days 3, 10, and 16.

$\ddagger \mathrm{GSH}$, reduced glutathione; GSSG, oxidized glutathione.

\$ BU, Baudhuin Units.

"Not done.

** Tested on day 16 .

catalase (Table II). To investigate further whether the enhancement of $\mathrm{H}_{2} \mathrm{O}_{2}$ release by azide was due primarily to inhibition of MPO or to inhibition of catalase, the dose-response curves for all three effects of azide were compared for monocytes on day 0 (Fig. 7). The release of $\mathrm{H}_{2} \mathrm{O}_{2}$ was augmented twofold, that is, $50 \%$ of the maximal increase, by $5 \mu \mathrm{M}$ azide. Essentially the same dose of azide $(4.2 \mu \mathrm{M})$ afforded $50 \%$ inhibition of MPO activity. Maximal stimulation of $\mathrm{H}_{2} \mathrm{O}_{2}$ release coincided with $86 \%$ inhibition of MPO activity, at $50 \mu \mathrm{M}$ azide. In contrast, catalase was inhibited $50 \%$ by as little as $0.5 \mu \mathrm{M}$ azide, a dose that enhanced $\mathrm{H}_{2} \mathrm{O}_{2}$ release only by $24 \%$. $90 \%$ inhibition of catalase by $5 \mu \mathrm{M}$ azide was associated with only a 2.1 -fold increase in $\mathrm{H}_{2} \mathrm{O}_{2}$ release. There was a small decrease in $\mathrm{H}_{2} \mathrm{O}_{2}$ release with concentrations of azide $>1 \mathrm{mM}$. This was not due to inhibition of the HPO used in the assay for $\mathrm{H}_{2} \mathrm{O}_{2}$ (data not shown).

The differential effects of inhibition of MPO and of catalase were even more striking using $\mathrm{KCN}$ instead of

TABLE III

Effect of Azide on $\mathrm{H}_{2} \mathrm{O}_{2}$ Release: Correlation with Spontaneous Decline in MPO Activity*

\begin{tabular}{|c|c|c|c|c|}
\hline \multirow{2}{*}{$\begin{array}{l}\text { Days of } \\
\text { culture }\end{array}$} & \multicolumn{2}{|c|}{$\mathrm{H}_{2} \mathrm{O}_{2}$ Release } & \multirow[b]{2}{*}{$+\mathrm{NaN}_{3} /-\mathrm{NaN}_{3}$} & \multirow{2}{*}{$\begin{array}{c}\text { Peroxidase } \\
\text { activity }\end{array}$} \\
\hline & $+\mathrm{NaN}_{3}(1 \mathrm{mM})$ & $-\mathrm{NaN}_{3}$ & & \\
\hline & \multicolumn{2}{|c|}{$n m o l / 60 \mathrm{~min} / \mathrm{mg}$ protein } & & $\times 10^{-2} \mathrm{UI}$ \\
\hline 0 & 599 & 139 & 4.31 & 24.8 \\
\hline 1 & 291 & 90 & 3.23 & 14.6 \\
\hline 2 & 510 & 439 & 1.16 & 8.6 \\
\hline 3 & 670 & 511 & 1.31 & 3.2 \\
\hline 4 & 102 & 118 & 0.86 & 2.2 \\
\hline 6 & 28 & 41 & 0.68 & 1.2 \\
\hline
\end{tabular}

* Values are means of triplicates.
$\mathrm{NaN}_{3}$, as shown in Fig. 8. Again, inhibition of MPO and augmentation of $\mathrm{H}_{2} \mathrm{O}_{2}$ release followed precisely the same dose-response curve. In contrast, complete inhibition of catalase by lower doses of $\mathrm{KCN}$ afforded no increase in $\mathrm{H}_{2} \mathrm{O}_{2}$ release. Thus, MPO rather than catalase appears to be responsible for profoundly reducing the amount of $\mathrm{H}_{2} \mathrm{O}_{2}$ that can be detected in the extracellular medium when monocytes are assayed within the first $3 \mathrm{~d}$ of culture.

\section{DISCUSSION}

Recent evidence implicating reactive oxygen intermediates in some of the antitumor and antimicrobial functions of mononuclear phagocytes (21-27) prompted this study of oxidative metabolism during the differentiation of human blood monocytes in vitro. As monocytes matured into macrophages, their capacity to release $\mathrm{O}_{2}^{-}$and $\mathrm{H}_{2} \mathrm{O}_{2}$ declined precipitously. Over the same time, their specific activity of SOD increased;

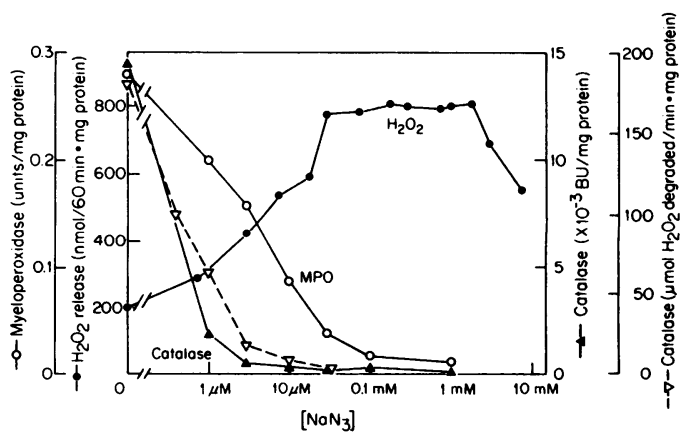

Figure 7 Effect of sodium azide on $\mathrm{H}_{2} \mathrm{O}_{2}$ release, catalase and myeloperoxidase activities of day 0 monocytes. $\mathrm{H}_{2} \mathrm{O}_{2}$ release was triggered with PMA $(100 \mathrm{ng} / \mathrm{ml})$. Catalase was measured both spectrophotometrically and polargraphically (Methods). Data are means from four experiments, in one of which the same cell preparation was used for intact cells and for lysates. BU, Baudhuin units. 


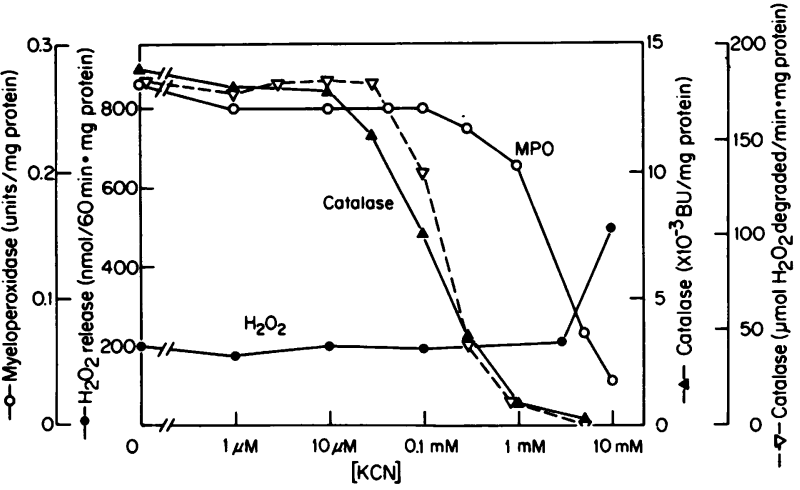

Figure 8 Effect of potassium cyanide on $\mathrm{H}_{2} \mathrm{O}_{2}$ release, catalase and myeloperoxidase activities of day 0 monocytes. See legend to Fig. 8.

MPO, catalase, and GPO decreased; and GR and the content of glutathione per milligram cell protein remained the same. Thus, the decrease with time in $\mathrm{H}_{2} \mathrm{O}_{2}$ release can probably not be attributed to increased catabolism of $\mathrm{H}_{2} \mathrm{O}_{2}$. Most likely, diminished capacity to release $\mathrm{O}_{2}^{-}$and $\mathrm{H}_{2} \mathrm{O}_{2}$ reflected diminished capacity to produce them.

The validity of these conclusions rests on the suitability of the assay conditions for adherent monocytes. The culture conditions supported the morphologic differentiation of monocytes into macrophages and frequently into giant cells, with a 15 -fold increase in the protein content per cell over a 4-wk period. We compared the release of $\mathrm{O}_{2}^{-}$and $\mathrm{H}_{2} \mathrm{O}_{2}$, in response to both soluble and particulate stimuli at optimal doses, under conditions not limited by $\mathrm{pH}$ or cell density, with inhibition of intracellular peroxidase and catalase. The same trends were observed whether the results were expressed per milligram cell protein or per cell.

At each time point tested, the $\mathrm{H}_{2} \mathrm{O}_{2}$ detected in the extracellular medium markedly exceeded the $\mathrm{O}_{2}^{-}$ detected from monocytes on matched coverslips. If $\mathrm{H}_{2} \mathrm{O}_{2}$ arose from dismutation of $\mathrm{O}_{2}^{-}$outside the cell, and if both compounds were detected with comparable efficiency, then one would expect to detect twice as much $\mathrm{O}_{2}^{-}$as $\mathrm{H}_{2} \mathrm{O}_{2}$ (41). Our contrary findings may suggest that oxygen is reduced to $\mathrm{O}_{2}^{-}$within the monocyte, at a site accessible to $\mathrm{SOD}$, so that $\mathrm{H}_{2} \mathrm{O}_{2}$ is more likely to be secreted than $\mathrm{O}_{2}^{-}$, when $\mathrm{H}_{2} \mathrm{O}_{2}$-catabolizing enzymes are inhibited. In support of this possibility was the decline in $\mathrm{O}_{2}^{-}$release on day 3 , at a time when SOD activity increased threefold and $\mathrm{H}_{2} \mathrm{O}_{2}$ release increased 1.4-fold, compared with day 0. Alternatively, some portion of oxygen reduction in monocytes may proceed by a 2-electron reaction, without an $\mathrm{O}_{2}^{-}$intermediate. Finally, neither the assay for $\mathrm{O}_{2}^{-}$nor the assay for $\mathrm{H}_{2} \mathrm{O}_{2}$ approaches $100 \%$ efficiency (43). The ratios of the two compounds detected may simply reflect the relative efficiencies of the assays under the conditions used. Reiss and Roos (17) reported that freshly isolated human monocytes stimulated in suspension with opsonized zymosan released $\sim 0.8 \mathrm{nmol}$ of both $\mathrm{H}_{2} \mathrm{O}_{2}$ and $\mathrm{O}_{2}^{-} / \mathrm{min}$ per $10^{6}$ cells. Our value for $\mathrm{H}_{2} \mathrm{O}_{2}$ release on day 0 agrees closely with theirs. The difference between the findings for $\mathrm{O}_{2}^{-}$release may be attributed in large part to our use of adherent cells (unpublished observations).

The predominant enzymatic scavengers of $\mathrm{H}_{2} \mathrm{O}_{2}$ in monocytes are probably MPO, catalase, and GPO. We do not know of a specific inhibitor of GPO, a selenoenzyme (44). Both azide and cyanide inhibit the heme enzymes, MPO and catalase. We found that MPO was much more important than catalase in limiting the amount of $\mathrm{H}_{2} \mathrm{O}_{2}$ detected in the extracellular medium. This conclusion was based on two findings. First, the dose-response curves were identical when comparing (a) the inhibition of MPO by azide or cyanide and ( $b$ ) their augmentation of $\mathrm{H}_{2} \mathrm{O}_{2}$ release. The same studies dissociated the inhibition of catalase from the augmentation of $\mathrm{H}_{2} \mathrm{O}_{2}$ release. Second, the enhancing effect of azide on $\mathrm{H}_{2} \mathrm{O}_{2}$ release decreased over $2 \mathrm{~d}$, precisely in parallel with the decline in MPO levels, but without relation to the decline in catalase, which was more gradual. The implications of the differential scavenging effects of MPO and catalase are not yet clear as regards the probable site of $\mathrm{H}_{2} \mathrm{O}_{2}$ formation in the monocyte. MPO is located in granules (45). However, some MPO is released into the extracellular medium during stimulation of the cells (46). We detected $6 \%$ of the MPO in the medium after exposure to PMA. MPO may then adhere to the outer face of the plasma membrane. The location of catalase in human monocytes is not certain. It may be cytosolic (47) or localized in granules (48). In a study of catalase-deficient subjects, Roos et al. concluded that catalase protects monocytes from external oxidative stress, whereas the glutathione redox cycle is more predominently involved in scavenging $\mathrm{H}_{2} \mathrm{O}_{2}$ during phagocytosis (37).

At least four explanations could be offered for the decline in $\mathrm{O}_{2}^{-}$and $\mathrm{H}_{2} \mathrm{O}_{2}$ releasing capacity after the 4th $\mathrm{d}$ of culture of monocytes. First, this could reflect functional heterogeneity of monocytes (49), with selective survival of cells less active in release of oxygen intermediates. This is unlikely to be the sole explanation. We could detect no difference in the $\mathrm{H}_{2} \mathrm{O}_{2}$-releasing capacity of adherent and nonadherent monocytes over the first $5 \mathrm{~d}$ of culture. Approximately $65 \%$ of the monocytes adherent on day 4 , when $\mathrm{H}_{2} \mathrm{O}_{2}$ release was comparable to that on day 0 , were still adherent on day 7 , when it was minimal. Second, there could be increased activity of $\mathrm{H}_{2} \mathrm{O}_{2}$ scavengers. As already noted, the specific activity of the presumed major scavengers of $\mathrm{H}_{2} \mathrm{O}_{2}$ in monocyte lysates actually declined or remained constant. However, it is possible that there 
were shifts in intracellular location of $\mathrm{H}_{2} \mathrm{O}_{2}$ scavenging systems that could promote their efficiency, or that there were increases in the activity of scavengers more important than those we tested. Third, there could be an acquired defect in the ability of the oxidase to be triggered by the soluble and particulate stimuli we used (24). Fourth, the number or activity of NAD(P)H oxidase molecules or their cofactors (50) might decrease, or the number or activity of regulatory molecules might increase $(51,52)$. Distinctions among these possibilities will probably have to await the development of assays for both the activity and the content of the oxidase, its cofactors, and its regulators.

Several other laboratories are also studying changes in monocyte oxidative metabolism with time in culture $(20,29)$. Some of their preliminary reports appear similar to our results (20), while others may possibly be discrepant (29). Comparison of culture conditions and assay methods will be desirable.

In the light of our findings, it is of considerable interest that many workers have noted decreased antimicrobial activity in human macrophages after 5 or more days in culture, compared with monocytes studied during the first $3 \mathrm{~d}$ of incubation. Such observations have been reported for Toxoplasma gondii (24), Leishmania, ${ }^{3}$ Herpes simplex (53), and Cryptococcus neoformans (54). The multiplication of microbes such as Mycobacterium leprae and Ricksettia mooseri within human macrophages after several weeks in culture has also been described $(55,56)$. However, some investigations have reported an increased bactericidal activity during culture of human monocytes $(57,58)$. Studies are needed in which monocyte antimicrobial activity and oxidative metabolism are studied simultaneously.

The appearance of giant cells in cultures of monocytes is a striking phenomenon that has been repeatedly observed $(1-3,6,7,9)$. We know very little about the metabolism or functions of these multinucleated cells or their responses to regulatory molecules. Also of considerable interest was the substantial portion of viable monocytes that became nonadherent after $4 \mathrm{~d}$ of culture. The nonadherent monocyte population is frequently overlooked in studies of monocyte physiology.

The changes in oxidative metabolism observed here stand in sharp contrast to increases in cell size, lysosomal hydrolase and ectoenzyme activity, endocytic capacity, and expression of cell surface receptors that are underway at the same time $(4,6-11)$. As has often been observed with tissue macrophages of laboratory animals, various features of cell structure and function do not necessarily change in a coordinate fashion during the differentiation of mononuclear phagocytes.

${ }^{3}$ Murray, H. Personal communication.
Based on the data presented here and earlier, ${ }^{1}$ we propose the following tentative, partial sequence of human monocyte differentiation. The normal blood monocyte has a capacity to secrete $\mathrm{O}_{2}^{-}$and $\mathrm{H}_{2} \mathrm{O}_{2}$ comparable to that of a granulocyte $(17,18)$ or an activated mouse tissue macrophage $(28,29)$. This capacity is decreased in monocytes collected from some patients with cancer, and elevated in some patients with infection, by mechanisms not yet understood. ${ }^{1}$ When the monocyte migrates from the vasculature into an inflammatory site, its oxidative capacity may be retained under the influence of lymphocyte mediators or other humoral factors. When the monocyte enters noninflamed tissue, its capacity to produce reactive oxygen intermediates may involute to resemble that of the resident peritoneal macrophage of the mouse $(28,29)$. During the remainder of the cell's lifespan, the remarkable capacity to secrete large amounts of $\mathrm{O}_{2}^{-}$and $\mathrm{H}_{2} \mathrm{O}_{2}$ may be reinduced by inflammatory mediators $(23,29-31)$. The above hypothesis contains key elements that have not yet been tested. Experiments are underway to do so.

\section{ACKNOWLEDGMENTS}

We thank Dr. Nadia Nogueira and Dr. Marcus Horwitz for helpful discussions concerning culture of monocytes, and Dr. Bradley Arrick for useful suggestions. We also thank Ms. Nancy DeSantis and Mrs. Linda Brukner for their technical assistance, and Mrs. Grace Silvestri and Miss Betty Broyles for typing this manuscript.

This work was supported by grants CA-22090 and AI07012 from The National Institutes of Health.

\section{REFERENCES}

1. Lewis, M. R. 1925. The formation of macrophages, epithelioid cells and giant cells from leukocytes in incubated blood. Am. J. Pathol. 1: 91-100.

2. Carrel, A., and A. H. Ebeling. 1926. The fundamental properties of the fibroblast and the macrophage. II. The Macrophage. J. Exp. Med. 44: 285-305.

3. Lewis, W. H. 1927. The formation of giant cells in tissue cultures and their similarity to those in tuberculous lesions. Am. Rev. Tuberculosis. 15: 616-628.

4. Cohn, Z. A., and B. Benson. 1964. The differentiation of mononuclear phagocytes. Morphology, cytochemistry, and biochemistry. J. Exp. Med. 121: 153-170.

5. Sutton, J. S. 1967. Ultrastructural aspects of in vitro development of monocytes into macrophages, epithelioid cells, and multinucleated giant cells. Natl. Cancer Inst. Monograph. 26: 71-141.

6. Bennett, W. E., and Z. A. Cohn. 1966. The isolation and selected properties of blood monocytes. J. Exp. Med. 123: $145-160$.

7. Johnson, W. D. Jr., B. Mei, and Z. A. Cohn. 1977. The separation, long-term cultivation, and maturation of the human monocyte. J. Exp. Med. 146: 1613-1626.

8. Zuckerman, S. H., S. K. Ackerman, and S. D. Douglas. 1979. Long-term human peripheral blood monocyte cultures: establishment, metabolism and morphology of primary human monocyte-macrophage cell cultures. Immunology. 38: 401-411.

9. Musson, R. A., H. Shafran, and P. M. Henson. 1980. Intra- 
cellular levels and stimulated release of lysosomal enzymes from human peripheral blood monocytes and monocyte-derived macrophages.J. Reticuloendothel. Soc. 28: $249-264$

10. Birmingham, J. R., and E. L. Jeska. 1980. The isolation, long-term cultivation and characterization of bovine peripheral blood monocytes. Immunology. 41: 807-814.

11. Newman, S. L., R. A. Musson, and P. M. Henson. 1980. Development of functional complement receptors during in vitro maturation of human monocytes into macrophages. J. Immunol. 125: 2236-2244.

12. Hammerstr $\emptyset \mathrm{m}, \mathrm{J}$. 1979. Human macrophage differentiation in vivo and in vitro. A comparison of human peritoneal macrophages and monocytes. Acta Pathol. Microbiol. Scand. Sect. 87: 113-120.

13. Clark, E. R., and E. L. Clark. 1930. Relation of monocytes of the blood to the tissue macrophages. Am. J. Anat. 46: $149-185$.

14. Reeves, D. L. 1934. A study of the in vivo and in vitro behavior of the monocytes of the blood stream and connective tissue. Bull. Johns Hopkins Hospital. 55: 245256.

15. Ebert, R. H., and H. W. Florey. 1939. The extravascular development of the monocyte observed in vivo. Br.J.Exp. Pathol. 20: 342-356.

16. Johnston, R. B., Jr., J. E. Lehmeyer, and L. A. Guthrie. 1976. Generation of superoxide anion and chemiluminescence by human monocytes during phagocytosis and on contact with surface-bound immunoglobulin G. J. Exp. Med. 143: 1551-1556.

17. Reiss, M., and D. Roos. 1978. Differences in oxygen metabolism of phagocytosing monocytes and neutrophils. J. Clin. Invest. 61: 480-488.

18. Nakagawara, A., K. Kayashima, R. Tamada, K. Onoue, K. Ikeda, and K. Inokuchi. 1979. Sensitive and rapid method for determination of superoxide-generating activity of blood monocytes and its use as a probe for monocyte function in cancer patients. Gann. 70: 829-833.

19. Kitagawa, S., F. Takaku, and S. Sakamoto. 1980. A comparison of the superoxide-releasing response in human polymorphonuclear leukocytes and monocytes. J. Immunol. 125: 359-364.

20. Aultman, M. D., and A. M. Kaplan. 1980. Production of superoxide anion by human monocytes. J. Reticuloendothel. Soc. la (Abstr.).

21. Murray, H. W., C. W. Juangbhanich, C. F. Nathan, and Z. A. Cohn. 1979. Macrophage oxygen-dependent antimicrobial activity. II. The role of oxygen intermediates. J. Exp. Med. 150: 950-964.

22. Sasada, M., and R. B. Johnston, Jr. 1980. Macrophage microbicidal activity. Correlation between phagocytosisassociated oxidative metabolism and the killing of Candida by macrophages. J. Exp. Med. 152: 85-98.

23. Nathan, C., N. Nogueira, C. Juangbhanich, J. Ellis, and Z. A. Cohn. 1979. Activation of macrophages in vivo and in vitro. Correlation between hydrogen peroxide release and killing of Trypanosoma cruzi. J. Exp. Med. 149: 1056-1068.

24. Wilson, C. B., V. Tsai, and J. S. Remington. 1980. Failure to trigger the oxidative metabolic burst by normal macrophages. Possible mechanism for survival of intracellular pathogens. J. Exp. Med. 151: 328-346.

25. Weiss, S. J., A. F. LoBuglio, and M. B. Kessler. 1980. Oxidative mechanisms of monocyte-mediated cytotoxicity. Proc. Natl. Acad. Sci. U. S. A. 77: 584-587.

26. Nathan, C. F., S. C. Silverstein, L. H. Brukner, and Z. A. Cohn. 1979. Extracellular cytolysis by activated macro- phages and granulocytes. II. Hydrogen peroxide as a mediator of cytotoxicity. J. Exp. Med. 149: 100-113.

27. Nathan, C., and Z. A. Cohn. 1980. Role of oxygendependent mechanisms in antibody-induced lysis of tumor cells by activated macrophages. J. Exp. Med. 152: 198-208.

28. Nathan, C. F., and R. K. Root. 1977. Hydrogen peroxide release from mouse peritoneal macrophages. Dependence on sequential activation and triggering. J. Exp. Med. 146: 1648-1662.

29. Johnston, R. B., Jr., C. A. Godzik, and Z. A. Cohn. 1978. Increased superoxide anion production by immunologically activated and chemically elicited macrophages. J. Exp. Med. 148: 115-127.

30. Kayashima, K., K. Onoue, A. Nakagawara, and S. Minakami. 1980. Superoxide anion-generating activities of macrophages as studied by using cytochalasin $E$ and lectins as synergistic stimulants for superoxide release. Microbiol. Immunol. 24: 449-461.

31. Murray, H. W., and Z. A. Cohn 1980. Macrophage oxygendependent antimicrobial activity. III. Enhanced oxidative metabolism as an expression of macrophage activation. J. Exp. Med. 152: 1596-1609.

32. Böyum, A. 1968. Isolation of mononuclear cells and granulocytes from human blood. Scand. J. Clin. Lab. Invest. 97(Suppl. 21): 77-90.

33. Kaplow, L. Simplified myeloperoxidase stain using benzidine dihydrochloride. Blood. 26: 215-219.

34. Lowry, O. H., H. J. Rosebrough, A. L. Farr, and R. J. Randall. 1951. Protein measurement with the Folin phenol reagent. J. Biol. Chem. 193: 265-275.

35. Steinman, R. M., and Z. A. Cohn. 1972. The interaction of soluble horseradish peroxidase with mouse peritoneal macrophages in vitro. J. Cell Biol. 55: 186-204.

36. Baudhuin, P., H. Beaufay, Y. Rahman-Li, O. Z. Sellinger, R. Wattiaux, P. Jacques, and C. de Duve. 1964. Tissue fractionation studies. 17. Intracellular distribution of monoamine oxidase, aspartate aminotransferase, alanine aminotransferase, D-amino acid oxidase, and catalase in rat liver tissue. Biochem. J. 92: 179-184.

37. Roos, D., R. S. Weening, S. R. Wyss, and H. E. Aebi. 1980. Protection of human neutrophils by endogenous catalase. Studies with cells from catalase-deficient individuals. J. Clin. Invest. 65: 1515-1522.

38. Paglia, D. E., and W. N. Valentine. 1967. Studies on the quantitative and qualitative characterization of erythrocyte glutathione peroxidase. J. Lab. Clin. Med. 70: $158-169$.

39. Roos, D., R. S. Weening, A. A. Voetman, M. L. J. van Schaik, A. A. M. Bot, L. J. Meerhof, and J. A. Loos. Protection of phagocytic leukocytes by endogenous glutathione: Studies in a family with glutathione reductase deficiency. Blood. 53: 851-866.

40. McCord, J. M., and I. Fridovich. 1969. Superoxide dismutase. An enzymic function for erythrocuprein. $J$. Biol. Chem. 244: 6049-6055.

41. McCord, J. M., C. O. Beaucamp, S. Goscin, H. P. Misra, and I. Fridovich. 1973. Superoxide and superoxide dismutase. In Oxidases and Related Redox Systems. T. E. King, H. S. Mason, and M. Morrison, editors. University Park Press, Baltimore. 51-66.

42. Tietze, F. 1969. Enzymic method for quantitative determination of nanogram amounts of total and oxidized glutathione: applications to mammalian blood and other tissues. Anal. Biochem. 27: 502-522.

43. Boveris, A., E. Martino, and A. O. M. Stoppani. 1977. Evaluation of the horseradish peroxidase-scopoletin 
method for the measurement of hydrogen peroxide formation in biological systems. Anal. Biochem. 80: 145-158.

44. Stadtman, T. C. 1980. Selenium-dependent enzymes. Annu. Rev. Biochem. 49: 93-110.

45. Bainton, D. F. 1980. Changes in peroxidase distribution within organelles of blood monocytes and peritoneal macrophages after surface adherence in vitro and in vivo. In Mononuclear Phagocytes. Functional Aspects. R. van Furth, editor. Martinus Nijhoff Publishers, The Hague. 61-86.

46. Homan-Müller, J. W. T., R. S. Weening, and D. Roos. Production of hydrogen peroxide by phagocytizing human granulocytes. J. Lab. Clin. Med. 85: 198-207.

47. Segal, A. W., and R. J. Peters. 1977. Analytical subcellular fractionation of human granulocytes with special reference to the localization of enzymes involved in microbicidal mechanisms. Clin. Sci. Mol. Med. 52: 429-442.

48. Nishimura, E. T., G. M. Whest, and H-Y. Yang. 1976. Ultrastructural localization of peroxidatic catalase in human peripheral blood leukocytes. Lab. Invest. 34: 60-68.

49. Norris, D. A., R. M. Morris, R. J. Sanderson, and P. F. Kohler. 1979. Isolation of functional subsets of human peripheral blood monocytes. J. Immunol. 123: 166-172.

50. Babior, B. M., and R. S. Kipnes. 1977. Superoxideforming enzyme from human neutrophils: Evidence for a flavin requirement. Blood. 50: 517-524.

51. Badwey, J. A., and M. L. Karnovsky. 1979. Production of superoxide and hydrogen peroxide by an NADH-oxidase in guinea pig polymorphonuclear leukocytes. Modulation by nucleotides and divalent cations. J. Biol. Chem. 254: 11530-11537.

52. Babior, B. M., and W. A. Peters. 1981. The $\mathrm{O}_{2}^{-}$-producing enzyme of human neutrophils. Further properties. J. Biol. Chem. 256: 2321-2323.

53. Daniels, C. A., E. S. Kleinerman, and R. Snyderman. 1978. Abortive and productive infections of human mononuclear phagocytes by type I Herpes simplex virus. Am. J. Pathol. 91: 119-129.

54. Diamond, R. D., and J. E. Bennett. 1973. Growth of Cryptococcus neoformans within human macrophages in vitro. Infect. Immun. 7: 231-236.

55. Samuel, D. R., T. Godal, B. Myrvang, and Y. K. Song. 1973. Behavior of Mycobacterium leprae in human macrophages in vitro. Infect. Immun. 8: 446-449.

56. Gambrill, M. R., and C. L. Wisseman, Jr. 1973. Mechanisms of immunity in Typhus infections. II. Multiplication of Typhus Rickettsiae in human macrophage cell cultures in the nonimmune system: Influence of virulence of Rickettsial strains and of chloramphenicol. Infect. Immun. 8: 519-527.

57. Cline, M. J. 1970. Bactericidal activity of human macrophages: Analysis of factors influencing the killing of Listeria monocytogenes. Infect. Immun. 2: 156-161.

58. McLeod, R., K. G. Bensch, S. M. Smith, and J. S. Remington. 1980. Effects of human peripheral blood monocytes, monocyte-derived macrophages, and spleen mononuclear phagocytes on Toxoplasma gondii. Cell. Immunol. 54: 330-350. 